Section Editor

Mitchell S.V. Elkind, MD, MS

Mystery Case:

\title{
Cowden syndrome presenting with partial epilepsy related to focal cortical dysplasia
}

Nicholas D. Child, $\mathrm{MBChB}$

Gregory D. Cascino, MD

Correspondence to

Dr. Child:

Child.Nicholas@mayo.edu

Figure $1 \quad$ MRI brain
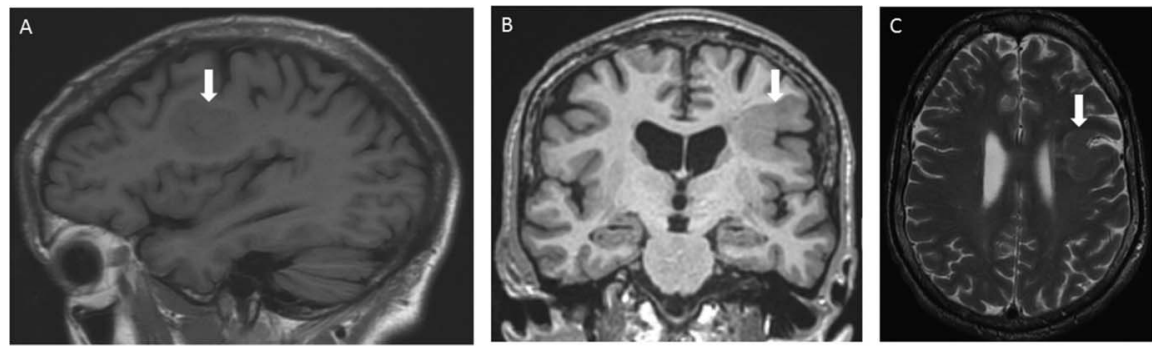

Sagittal T1-weighted MRI (A), oblique-coronal T1-weighted MRI (B), and axial T2-weighted MRI (C) show focal cortical dysplasia with abnormal sulcation involving the middle and inferior frontal gyrus posteriorly on the left with T2 signal extending to the ventricular surface thought to represent neuronal migration lines.
Figure 2 Skin changes found in Cowden syndrome

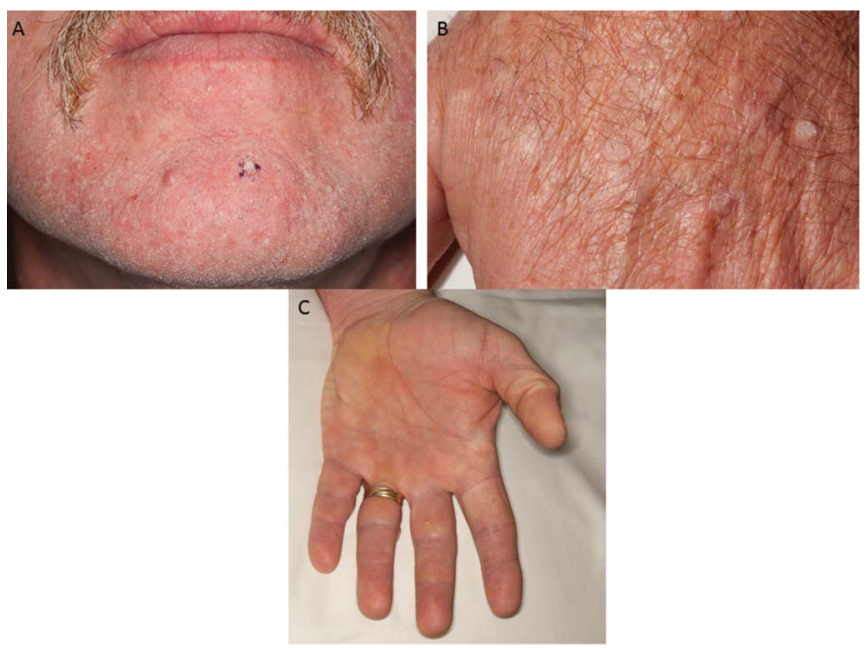

Skin examination revealed cobblestoning over the lower jaw $(A)$, acral keratoses over the dorsal hands (B), and palmar pitting (C).

Download teaching slides: www.neurology.org terized by "tightening" of the right side and variable loss of awareness. EEG showed focal epileptogenic abnormalities over left and midline central regions. MRI showed left frontal focal cortical dysplasia (figure 1). He had multiple skin lesions (figure 2) and colonoscopy revealed gastrointestinal mucosal ganglioneuromas. Genetic testing of PTEN gene confirmed a diagnosis of Cowden syndrome (CS).
CS is an autosomal dominant condition of hamartomas and tumors. ${ }^{1} \mathrm{MRI}$ is abnormal in 35\%, commonly showing dysplastic gangliocytomas of cerebellum, meningiomas, and vascular malformations. ${ }^{2}$ CS has not been reported presenting with partial epilepsy and focal cortical dysplasia.

\section{AUTHOR CONTRIBUTIONS}

N.D. Child and Dr. Cascino contributed to drafting and revising the manuscript. Dr. Cascino was responsible for the study concept.

\section{STUDY FUNDING}

No targeted funding reported.

\section{DISCLOSURE}

N. Child reports no disclosures. G. Cascino serves as an Associate Editor for Neurology ${ }^{\circledR}$. Go to Neurology.org for full disclosures.

\section{REFERENCES}

1. Farooq A, Walker LJ, Bowling J, Audisio RA. Cowden syndrome. Cancer Treat Rev 2010;36:577-583.

2. Lok C, Viseux V, Avril MF, et al. Brain magnetic resonance imaging in patients with Cowden syndrome. Medicine 2005;84:129-136
MYSTERY CASE RESPONSES The Mystery Case series was initiated by the Neurology ${ }^{\circledR}$ Resident $\&$ Fellow Section to develop the clinical reasoning skills of trainees. Residency programs, medical student preceptors, and individuals were invited to use this Mystery Case as an educational tool. Responses were solicited through a group e-mail sent to the American Academy 
of Neurology Consortium of Neurology Residents and Fellows and through social media. All the answers that we received came through social media, from individuals rather than groups. Most of the respondents $(61 \%)$ indicated a putative diagnosis of tuberous sclerosis (TS) as the most likely etiology. Other considerations included focal cortical dysplasia, as well as demyelinating or infectious processes. The most complete answer came from Dr. Pedro Serrano Castro (Spain). In his response, he pointed out that the left parietal cortex is dysplastic and that the cutaneous lesions are suggestive of mTOR pathway dysfunction as seen in CS.
The cortical and subcortical tubers seen in TS have a different appearance on brain MRI with a low T1 and a high T2/fluid-attenuated inversion recovery signal. Other MRI diagnostic criteria for TS include the presence of subependymal nodules, subependymal giant cell astrocytomas, and cerebral white matter migration lines.

This Mystery Case illustrates the rare finding of a focal cortical dysplasia in a patient with CS.

Dragos A. Nita, MD, PhD

The Hospital for Sick Children, University of Toronto, Canada. 


\section{Neurology}

\section{Mystery Case: Cowden syndrome presenting with partial epilepsy related to focal cortical dysplasia \\ Nicholas D. Child and Gregory D. Cascino}

Neurology 2013;81;e98-e99

DOI 10.1212/WNL.0b013e3182a55ef0

This information is current as of September 23, 2013

\section{Updated Information \& Services}

Supplementary Material

References

Citations

Subspecialty Collections

\section{Permissions \& Licensing}

Reprints including high resolution figures, can be found at: http://n.neurology.org/content/81/13/e98.full

Supplementary material can be found at: http://n.neurology.org/content/suppl/2013/09/21/81.13.e98.DC1

This article cites 2 articles, 0 of which you can access for free at: http://n.neurology.org/content/81/13/e98.full\#ref-list-1

This article has been cited by 1 HighWire-hosted articles: http://n.neurology.org/content/81/13/e98.full\#\#otherarticles

This article, along with others on similar topics, appears in the following collection(s):

\section{All Genetics}

http://n.neurology.org/cgi/collection/all_genetics

Cortical localization

http://n.neurology.org/cgi/collection/cortical_localization

Gastrointestinal

http://n.neurology.org/cgi/collection/gastrointestinal

Partial seizures

http://n.neurology.org/cgi/collection/partial_seizures

Information about reproducing this article in parts (figures,tables) or in its entirety can be found online at:

http://www.neurology.org/about/about_the_journal\#permissions

Information about ordering reprints can be found online: http://n.neurology.org/subscribers/advertise

Neurology ${ }^{\circledR}$ is the official journal of the American Academy of Neurology. Published continuously since 1951, it is now a weekly with 48 issues per year. Copyright (C 2013 American Academy of Neurology. All rights reserved. Print ISSN: 0028-3878. Online ISSN: 1526-632X.

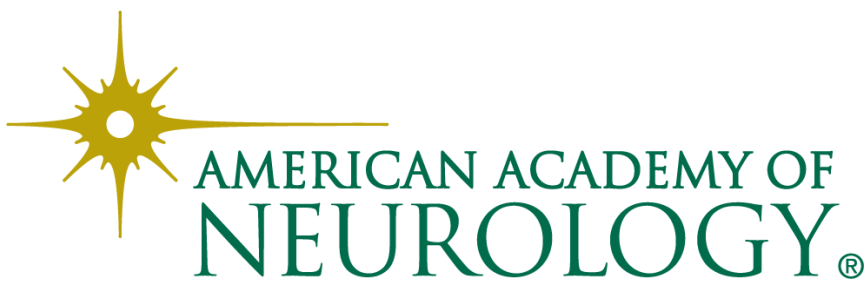

